\title{
The spatial dynamics of financial activities in Beijing: agglomeration economies and urban planning
}

\author{
Fenghua Pan ${ }^{\mathrm{a}}$, Sarah Hall ${ }^{\mathrm{b}}$ and Hua Zhang ${ }^{\mathrm{a}}$ \\ ${ }^{a}$ Beijing Key Laboratory of Environmental Remote Sensing and Digital Cities, \\ Faculty of Geographical Science, Beijing Normal University, Beijing, China; ${ }^{b}$ School \\ of Geography, The University of Nottingham, Nottingham, UK
}

Corresponding author: Hua Zhang, E-mail: zhanghua@bnu.edu.cn

\begin{abstract}
Beijing is widely recognised as the leading political, cultural, education and innovation center in China. However, its role as a financial center in national and international financial landscapes is less well understood, partly because the political, popular and academic focus has, until recently focused on Shanghai as mainland China's leading financial center. In response, this paper specifies the development and change of Beijing as an international financial canter by focusing on the geographies of financial activities within the city. Over the last two decades, financial activities have grown rapidly in Beijing and become more geographically concentrated. Two key financial districts are developing in Beijing: one in Financial Street and one in the Central Business District. The paper argues that the spatial patterns of financial activities in Beijing have been driven by both market and state forces. Drawing on the findings of a regression analysis, the paper reveals the role of municipal policy and planning alongside agglomeration economies in shaping the financial geographies of international financial centers.
\end{abstract}

Keywords: international financial centres; financial service firms; international financial districts; agglomeration economy; urban planning 


\section{Introduction}

Reflecting their rapid economic growth, cities from emerging economies are growing to be important nodes in the global financial landscape (Bassens et al., 2013; Pollard \& Samers, 2007; Pan et al., 2018). In this respect, Chinese cities like Beijing and Shanghai have rapidly increased their significance within rankings of global cities and financial centres in recent years (Taylor et al., 2014; Yao \& Shi, 2012; Taylor et al., 2013; Timberlake et al., 2014; Chubarov \& Brooker, 2013; Wei \& Yu, 2006; Yusuf \& Wu, 2002; Zhang, 2013). However, in the case of China, the specific role of each city is heavily shaped by national economic planning policies and the development of national champions in different sectors. In this respect, Shanghai has been designated at the national level to be China's leading international financial center (IFC). This designation means that Beijing holds a very distinctive place in China's financial center landscape. Although it was pointed out more than 10 years ago that Beijing was the most competitive financial center within mainland China (Zhao, Zhang \& Wang, 2004), it remains the case that Shanghai has been far more widely recognized as the leading financial center in mainland China (Karreman \& van der Knaap, 2009).

However, Beijing's municipal government has sought to strengthen the city's financial function in order to enhance its power within both national and global financial center networks. In the past two decades, the financial sector in Beijing has experienced unprecedented growth and tremendous spatial restructuring as seen in a number of measures including: the composition of financial services output and employment in the city (Zhao et al., 2004; Wójcik, Knight \& Pažitka, 2018); and the presence of key financial institutions and financial infrastructure (Wójcik et al., 2018; Engelen \& Grote, 2009). The financial sector accounted for $17.1 \%$ of the GDP of Beijing in 2016, the highest proportion for all cities within mainland China. In terms of employment in the financial sector, Beijing has outperformed other cities within mainland China since 2006 in terms of size. In 2016, the total employment of the financial sector in Beijing was as large as 538,000. 
Alongside the growing size of the financial services sector, the spatial pattern of financial activities within Beijing has changed significantly and several financial districts have emerged. The geographical distribution and clustering process of financial activities within IFCs are crucial to understand the evolution of an IFC from an urban geography perspective and can often provide indications of the changing composition of different types of financial services activity within any given city. For example, the growth of international investment banks is reflected in the expansion of London's historic financial district eastwards into Canary Wharf. More recently the rise of hedge funds and asset managers can be seen in the clustering of these firms west of the City of London in Mayfair. By examining in more detail the urban locational dynamics of financial activities within the city, this study seeks to explore the development of Beijing as an IFC.

The agglomeration of financial activities is common across IFCs and reflects the balance between centripetal and centrifugal forces (Cook et al., 2007). However, these are enacted in city specific ways, reflecting the unique development trajectory (Engelen \& Grote, 2009; Engelen, 2007; Grote, 2003) and institutional context of different IFCs (French, Leyshon \& Wainwright, 2011). There are particular benefits to exploring these intra center locational dynamics within an emerging IFC such as Beijing. The geographies of financial activities within IFC in China are influenced by its unique institutional settings, which are different from their Western counterparts (Zhao, 2013). On the one hand, the financial sector in China is highly regulated by the central government and state-owned financial institutions, such as banks, securities firms and institutional investors play central roles in the market (Walter \& Howie, 2011). On the other hand, the ambitious municipal governments in China have paid increasing attention to the development of the financial sector and aimed to develop national and international financial centers (Zhao et al., 2004). Creating financial districts in these metropolitan cities has become a viable way to achieve their development goal, in ways which reflect the longer history of developing industrial parks as a developmental strategy for Chinese cities over the last three decades. 
As financial services have developed in Beijing over the last two decades, the intra city spatial form of financial service sector has changed within the city. Drawing on comprehensive firm level data from the National Census of Basic Units in 1996 and 2001, and registration information of industrial and commercial firms in 2010, this study uses Beijing as a case to show the spatial clustering process of financial activities, thereby going some way to addressing the extant focus on financial centers in the global north (Lai, 2012; Robinson, 2002). This focus is important given the growing importance of China within global finance landscape (Walter \& Howie, 2011).

The key contribution of this study is that it demonstrates that both market and state forces have driven the spatial pattern of financial activities in Beijing. In particular, the financial districts of Beijing have been largely planned and shaped by state actors. By reporting on the resulting emergence of distinct financial clusters within Beijing, the paper represents the first geographical analysis of Beijing's transformation as an IFC based on firm level data. Moreover, it unpacks the development trajectory of the most influential financial cluster in Beijing, Financial Street, which provides new empirical evidence on how financial clusters has evolve and develop in an IFC in a transitional economy.

\section{Understanding the geographies of financial activities within Beijing}

The hierarchy of IFCs within global finance has been relatively stable in recent years. For example, and most notably, despite the significant changes to the international financial system following the 2007-8 financial crisis, London and New York have maintained their position as leading IFCs (Wójcik, 2013; Faulconbridge, 2004; Clark, 2002) and the so called NY-LON connection between London and New York remains a key driver within global finance as well as a source of financial innovation (Knox-Hayes, 2009; Wójcik, 2013). In addition to these two cities, it is now well recognised that there are several second-tier IFCs, mostly located in advanced economies including Hong Kong, Singapore, Tokyo, Frankfurt, Luxemburg, and Amsterdam. The most common explanation put forward for this is that there are significant path dependent advantages for incumbent leading financial centers as a 
result of the well-established agglomeration economies within them (Sassen, 2001). Thus, the financial clusters within these cities have partly underpinned the competitiveness of the IFCs.

\section{Agglomeration (dis)economies in the clustering of financial activities}

More recently, attention has focused on the dynamics within financial activities agglomeration economies. For example, New York's financial center has extended out of its history base in Wall Street to Midtown whilst London's financial center in the City of London has expanded both west into Mayfair and East into Canary Wharf and Old Street (Cook et al., 2007; Gong \& Keenan, 2012). Like other industrial clusters, the financial districts enjoy the benefits of agglomeration economies, including those from the agglomeration of firms within the same sector (localization economies) and across sectors (urbanization economies) (Puga, 2010; Duranton \& Puga, 2004) and underpin the competitiveness of a city and even a country (Porter, 1980). For example, research in London shows that the agglomeration of financial service firms can help innovate and diffuse knowledge that is vital to the production of bespoke financial products, tailored to the needs of particular clients (Cook et al., 2007). Meanwhile, the New York case shows that, although some financial service firms left Manhattan after 11 September 2001, many firms returned shortly after that due to the unique location attributes of the district (Gong \& Keenan, 2012). Admittedly, the growing costs of being located in the central area, a typical consequence of agglomeration diseconomies, can also crowd out some financial service firms (Cook et al., 2007).

Not surprisingly, those financial districts in IFCs evolve with time but are typically centered upon some key financial institutions, such as a central bank, a stock exchanges and the office of large international financial service firms. For instance, the Bank of England and London Stock Exchange are both located in the city of London. New York is also a case to this point (Cassis \& Wójcik, 2018). As a result of the liquidity and regulatory benefits, the financial districts within IFCs attract significant clusters of financial institutions (Clare, Gulamhussen \& Pinheiro, 2013), investors and highly 
skilled financial workers (Beaverstock, 2005; Beaverstock \& Hall, 2012).

In this sense, Beijing as an emerging IFC is no different to leading IFCs such as New York and London. For instance, as the capital of China, almost all the top financial regulators and national financial flagship institutions are headquartered in Beijing. The reform and opening of the financial sector in China have been slower than other sectors, thus many key financial institutions in China have a shorter history compared to their Western counterparts. Indeed many national financial regulators currently located in Beijing were not established until the early 1990s. For instance, the China Securities Regulatory Commission (CSRC), was set up in 1992. The China Insurance Regulatory Commission (CIRC) and China Banking Regulatory Commission (CBRC) were established in 1998 and 2003, respectively. Moreover, many national financial flagships ${ }^{1}$ restructured (becoming publicly listed firms) and located their headquarters within Beijing in the last two decades.

\section{Institutional efforts in building up financial districts}

Due to the significance of IFCs in strengthening and sustaining the competiveness of countries within finance led capitalism (Leyshon \& Thrift, 1997), many emerging economies have aimed to build up their own IFCs as a part of a wider economic development strategy (Cassis \& Wójcik, 2018). An important factor in shaping the relative fortunes of IFCs is state and regulatory support. For instance, regulatory changes have been used to maintain the attractiveness of IFCs to financial institutions, perhaps most notably in the case of London in the mid-1980s as it sought to compete with New York (Kynaston, 2002). More recently, Hong Kong and Singapore have used state support to facilitate their growth as IFC (Woo, 2015) and London has sought to use regulatory changes to facilitate its development as an offshore RMB center (Hall, 2018)

Not surprisingly, China has been long interested in developing its own mainland IFCs and Shanghai has been supported by the central government to become an IFC

\footnotetext{
1 They denote those large state-owned financial firms, such as the Big Four state-owned banks, including Industrial and Commercial Bank of China, Bank of China, China Construction Bank and Agricultural Bank of China.
} 
since the 1980s (SHMG, 1986; SHMG, 2001; CSC, 2009). Although Beijing has never been identified as the chosen city to become China's lead financial center, the importance of Beijing as a key financial center in China's financial system has been recognized for some time (Liu \& Wu, 2008; Zhao, 2013; Zhao et al., 2004). This is supported by more recent studies that have confirmed that Beijing plays an increasingly important role in China's financial center networks (Pan et al., 2017; Pan, Zhao \& Wojcik, 2016).

Reflecting the success of London and New York as IFCs, municipal authorities in financial centers in China have increasingly used these cities as exemplars upon which to model their planned development of financial services, particularly in terms of the development of discrete financial districts (Lai, 2012). For example, in the case of Beijing, the municipal government has used planning policy to encourage financial activity agglomeration in specific designated districts of the city since early 1990s. In the master plan of Beijing (1991-2010) approved by the state council in 1993, Financial Street located in Xicheng District and the Central Business District (CBD) located in Chaoyang District, were planned to become dual business centers of the city (Zhou, 1998). In particular, Financial Street was considered the key financial district by policy makers. It was written in the master plan that Financial Street would be "the national regulation center of the financial industry" and to be "home for the headquarters of national banks and other large financial institutions." This echoes the wider national framing of Beijing as the domestic financial center whilst Shanghai was intended to develop as China's IFC. In 1992, a developing company "Jinrongjie Holding" was established to be in charge of developing this area to become financial district. With the rapid growth of Financial Street, this area was positioned as the core of the financial center of Beijing according to a strategic plan for the development of financial industry published in 2008 (BJMC \& BJMG, 2008). In this strategic plan, the CBD was planned to be a secondary center of the financial cluster in Beijing. In addition, "three emerging 
financial districts" and "four back office financial districts" were proposed. In 2012, it was announced at the Eleventh Party Congress of Beijing that Financial Street will be built into the "nation's financial center"4.

These plans for the development of a municipally planned financial district within Beijing build in part on the location of some national financial institutions within China. Take Financial Street for example. The key point for the development of Financial Street was that the People's Bank of China (PBC), China's central bank, moved its headquarters to this district in 1988. Another milestone in the development of Financial Street was that the China Securities Regulatory Commission (CSRC) moved into this district in 1996. Later, the China Insurance Regulatory Commission (CIRC) and China Banking Regulatory Commission (CBRC) were set up and headquartered within this district in 1998 and 2003, respectively. After that more large domestic and foreign financial companies also moved their headquarters into this district. This shows that Beijing has sought to purposely plan its financial districts to capitalize on its unique strengths as a capital city, particularly in terms of already existing financial institutions and regulatory functions. Consequently, the political intentions of the municipal government as well as the economic growth of China's domestic financial services sector are both important in understanding the growing importance of Financial Street as a financial district.

\section{The spatial patterns of Beijing's financial activities over time}

The growth of Beijing as a financial center over the last 20 years can be seen clearly in financial employment figures. In 1996, the total employment in this sector was only 66,940 . Five years later, the figure doubled to 136,957 . In 2010, the figure doubled again to 292,770 . With the rapid growth of the finance sector, financial activities that were initially concentrated on Financial Street have expanded to other parts of the city, notably the Central Business District. This has also been facilitated by the municipal

\footnotetext{
2 It includes the West district of Zhongguancun, Transport business district in the eastern second ring road and Lize business district.

3 It includes Haidian Daoxianghu, Chaoyang Jinzhan, Tongzhou Xincheng and Xicheng Desheng back office financial districts.

4 http://district.ce.cn/newarea/roll/201207/05/t20120705_23464006_2.shtml
} 
government of Beijing that has sought to stimulate this part of the city in order to emulate other IFCs (BJMC \& BJMG, 2008). Drawing on the firm level data of 1996, 2001 and $2010^{5}$, this section will explore the geography of the finance sector in Beijing, paying special attention to the major financial service clusters.

\section{The changing geographies of the finance service firms within Beijing}

Figure 1 shows the geography of financial activities of Beijing in 1996, 2001 and 2010 based on employment in financial services. These charts show that significant financial services sector employment has been accompanied by a changing intra-center clustering within Beijing's financial landscape.

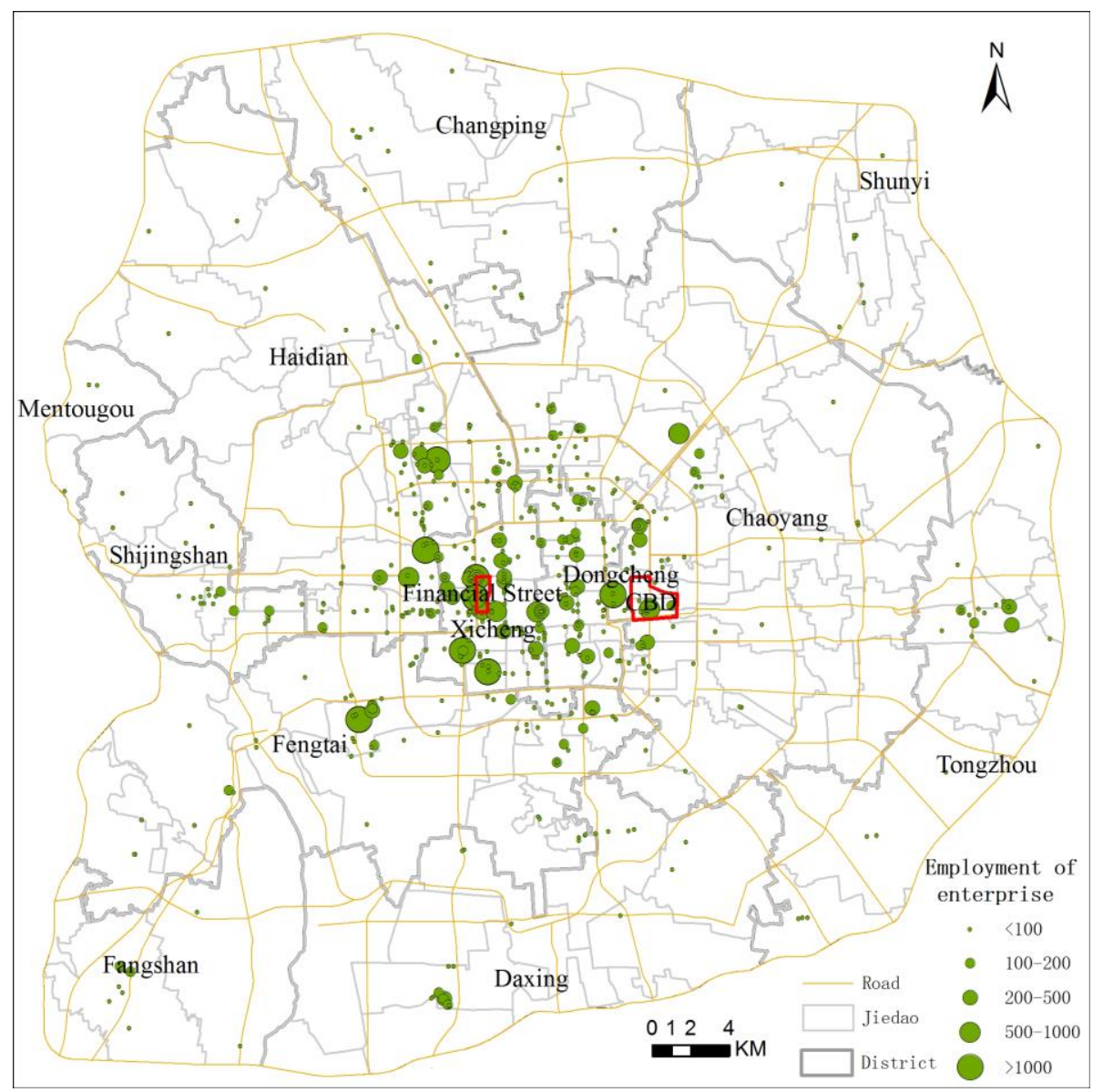

(a) 1996

5 Data of 1996 and 2001 are drawn from the first and second Basic Unit Survey, and the data of 2010 are drawn from Firm Database of Beijing purchased from Xinhuaxin company. 


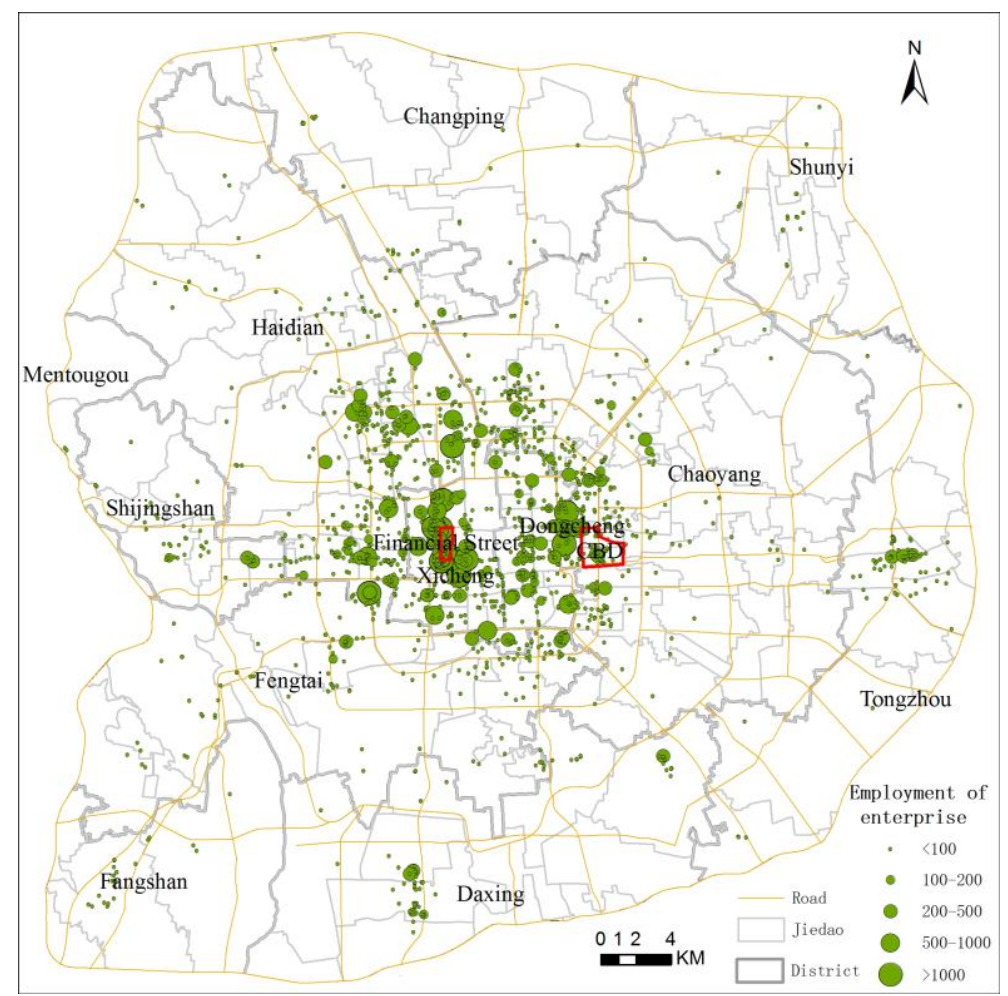

(b) 2001

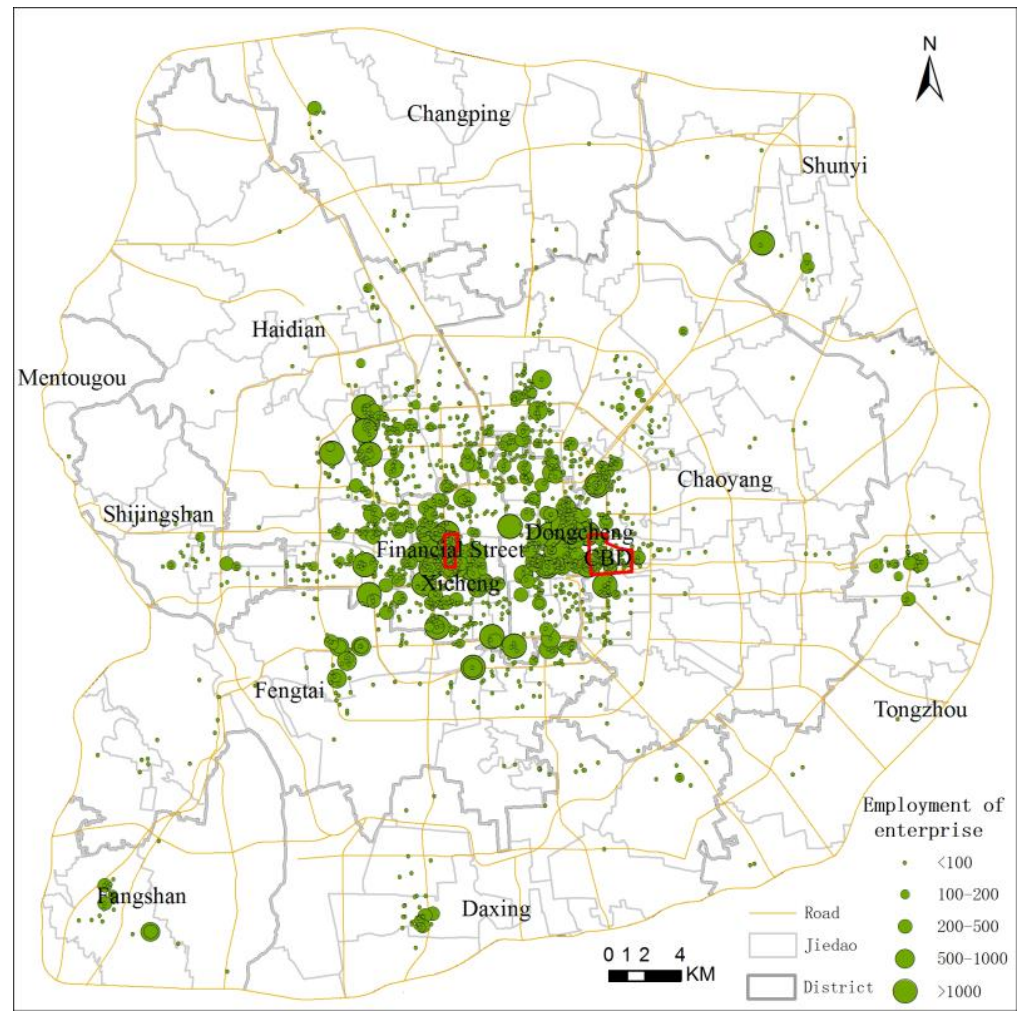

(c) 2010 
Figure 1. Distribution of financial employment of Beijing in 1996, 2001 and 2010

The distribution of financial activities among the different ring roads that shape Beijing's urban form shows that the financial sector had become more agglomerated in the inner city. In 1996, over $71 \%$ of the financial employment were concentrated within the fourth ring road, and the figure grew to $83 \%$ in 2010 . In addition, financial activities were increasingly seeking to concentrate even closer to the city center within the second ring road area. The employment of the financial sector within the second ring road accounted for $33.8 \%$ of that in the whole city in 2010 , rising from $26.3 \%$ in 1996 .

\section{Major financial service clusters in the city}

The kernel density analysis based on employment in financial sector shows that some financial service clusters have emerged over time (Figure 2). Kernel density estimation is a non-parametric way to estimate the probability density function of a random variable (Botev, Grotowski \& Kroese, 2010). It can help to smooth the distribution of financial employment and identify the high density regions, which are the financial service clusters. In 1996, there were several small clusters of financial activities in Beijing. Five years later, Financial Street stood out as a significant cluster of financial industry, though still not large in size. In 2010, Financial Street grew to be an even larger cluster of financial service. At the same time, the CBD area also became an important financial service cluster. The dual centers of the financial industry of Beijing finally emerged. In addition, Zhongguancun area, which is not in the central city but along the $4^{\text {th }}$ ring road, also emerged as an important financial district. 


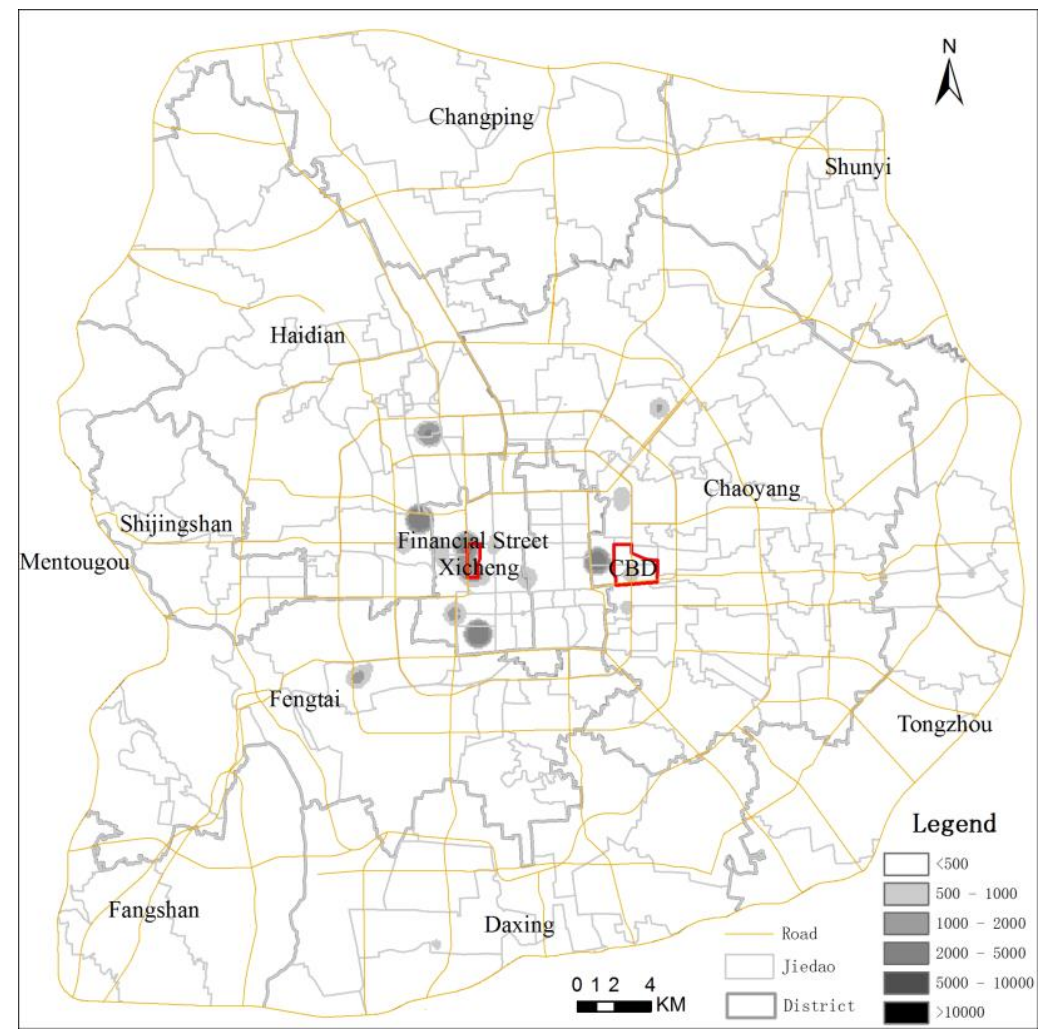

(a) 1996

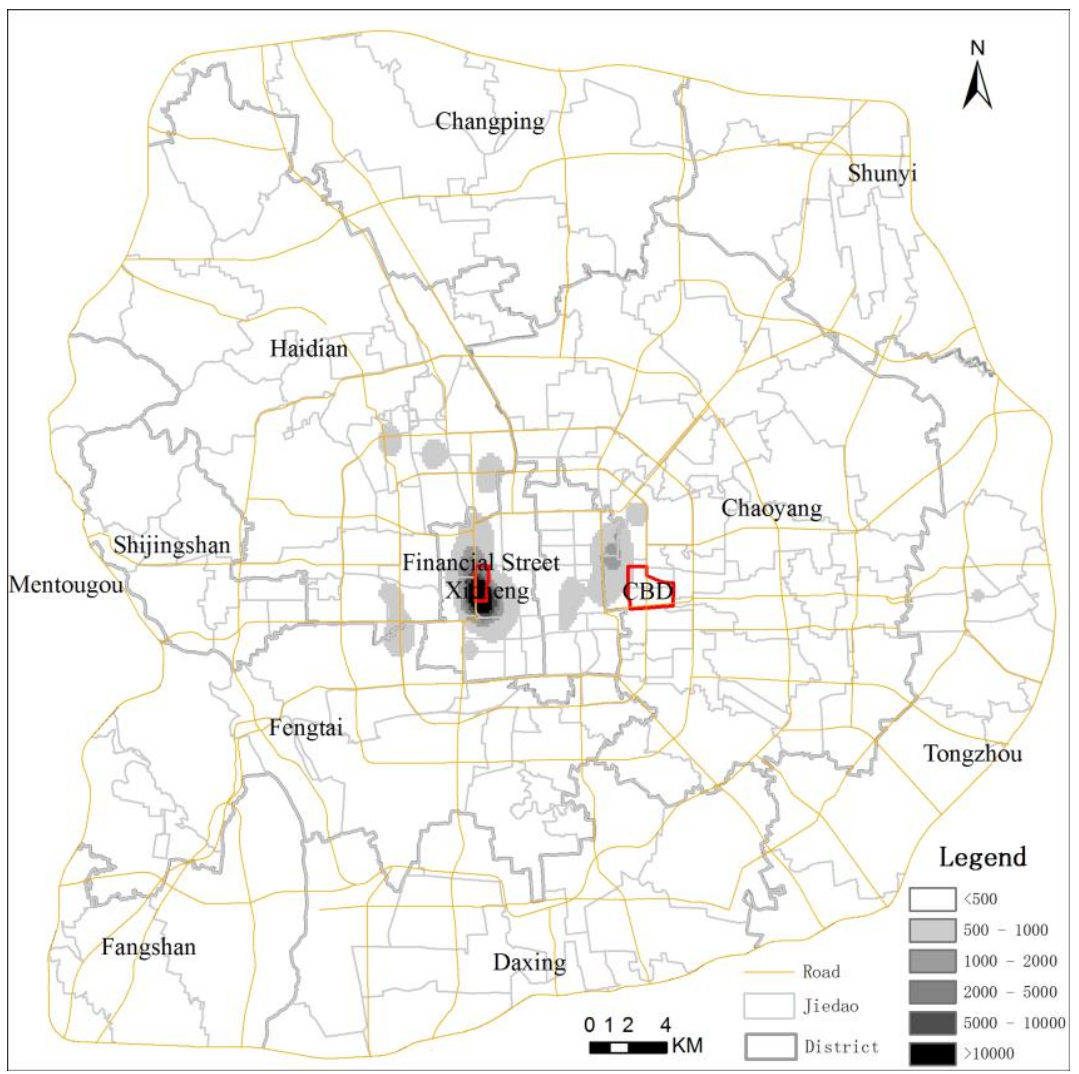

(b) 2001 


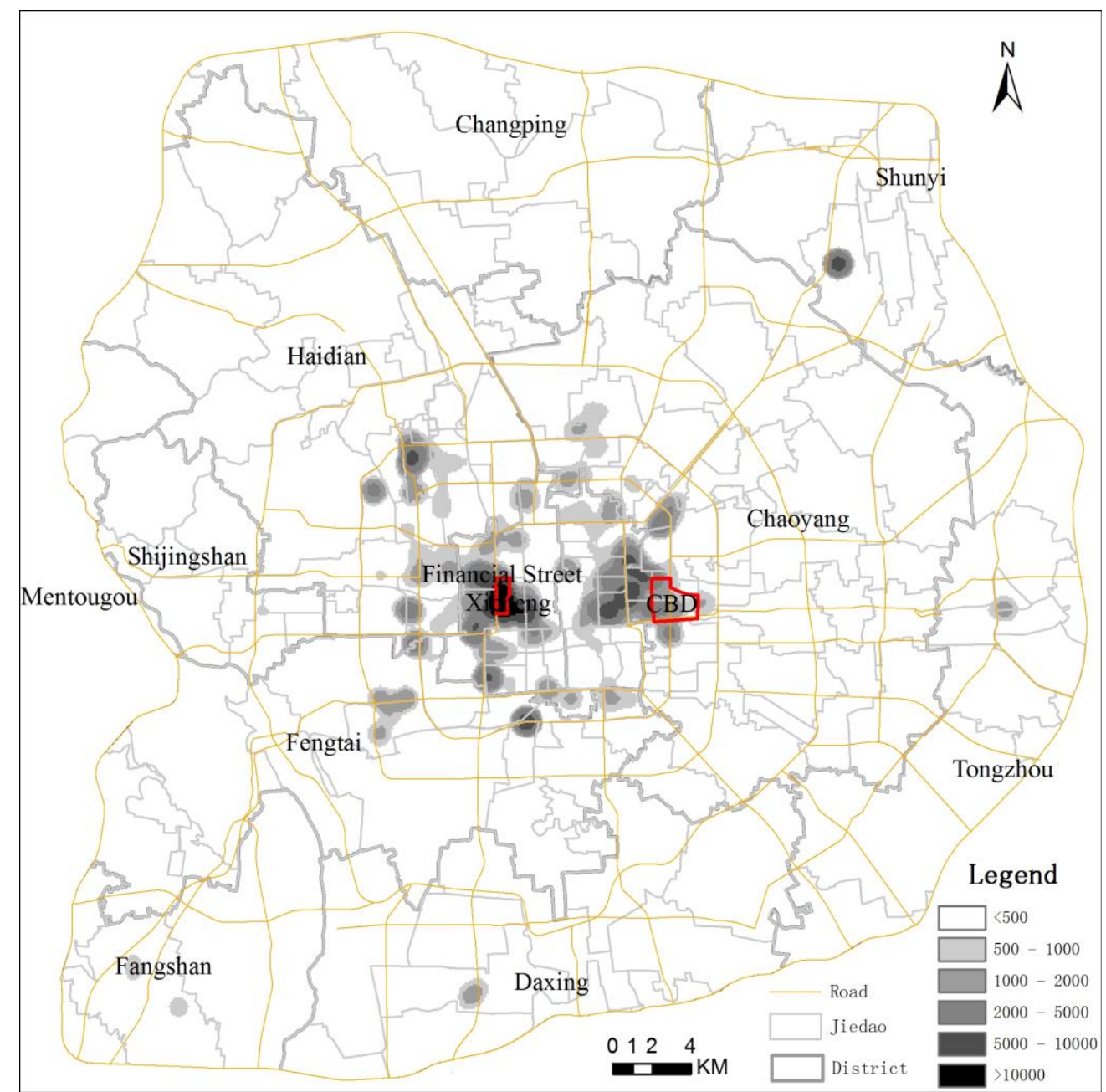

(c) 2010

Figure 2. Kernel Density Map of the Beijing's financial employment in 1996, 2001 and 2010

The functions of the two lead financial districts are distinct in terms of the financial service activities that they house. The distribution of headquarters of financial companies in sub-sectors including banking, insurance, securities, mutual funds and venture capital (private equity funds included) ${ }^{6}$ are shown in Figure 3. Financial Street and the CBD stand out as the home to most headquarters of important financial institutions. However, whilst Financial Street has more headquarters of banks, securities companies, the $\mathrm{CBD}$ and its neighboring areas have more headquarters of

6 The information of the headquarters is drawn from the following websites: http://finance.ce.cn/jrjg/index.shtml and http://pe.pedaily.cn/201412/20141204374720.shtml. 
insurance and venture capital companies. While venture capital companies are in the $\mathrm{CBD}$, they have also clustered in areas where the technology firms' cluster. As shown in the Figure 3, Zhongguancun area has many venture capital companies, indicating it might become a new financial service cluster focusing on high-tech investments due to its locational advantages being close to so many good universities and research institutions. With the ongoing reform and opening up of China's financial market, new type of financial business such as the venture capital sector has been booming, which has reshaped the functions and geographies of Beijing's financial activities (Zhang, 2011; Pan, Zhao \& Wójcik, 2016).

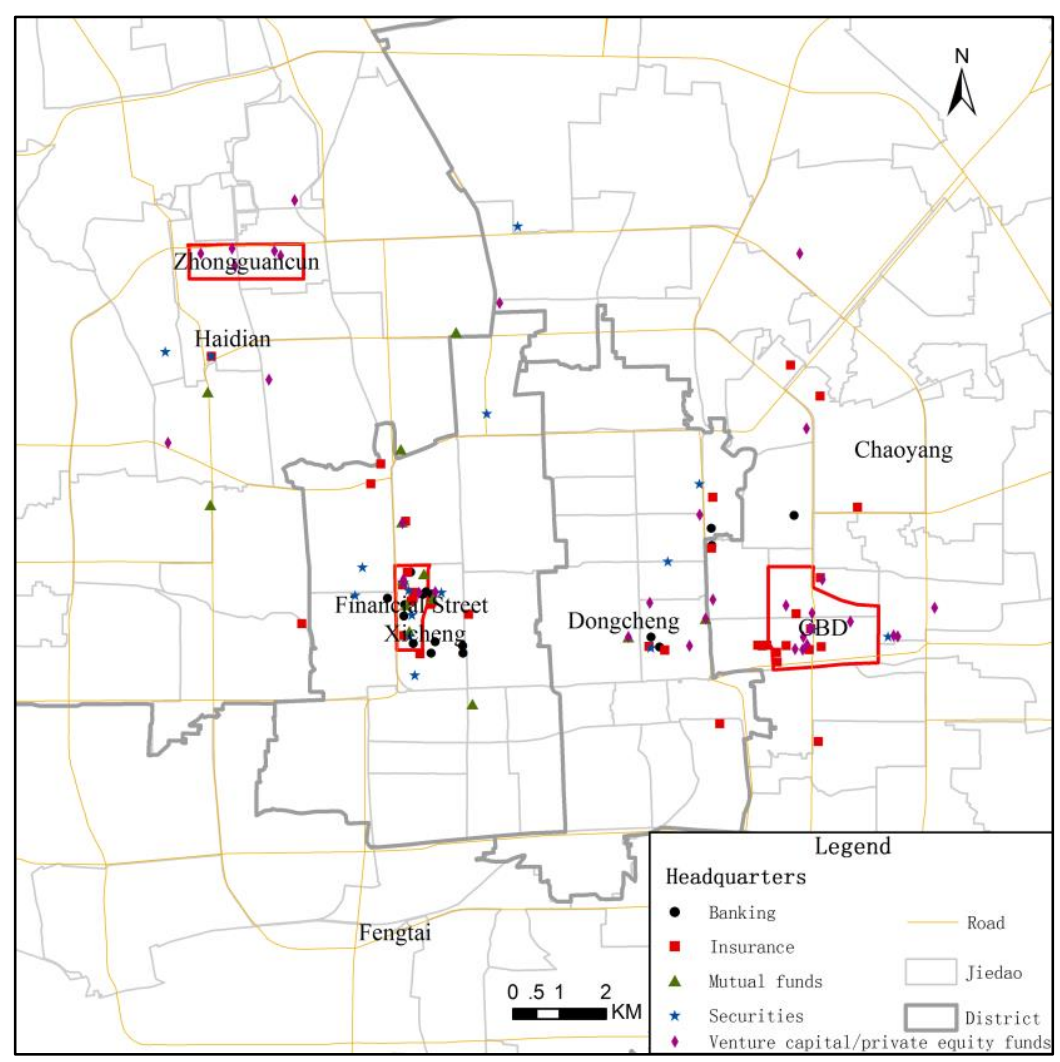

Figure 3. Distribution of headquarters of large financial companies in Beijing

\section{Regression analysis on the geographies of financial service firms in Beijing}

The locational behavior of financial activities within and across IFC has attracted a lot of research attention, although most cases are drawn from Western economies (Beaverstock, 2004; Pain, 2008; Gong \& Keenan, 2012; Cook et al., 2007). In this 
section, we test how agglomeration economies and institutional factors have influenced the locational behaviors of financial service firms within Beijing. First, to benefit from agglomeration economies, financial service firms might prefer to locate near competitors and other related advanced producer service firms to improve information accessibility and share infrastructure. The information spillover usually comes from geographical agglomeration of competitors and related institutions and firms. Being close to financial services and other related high-end service firms, they can enjoy agglomeration economies through sharing, matching and learning mechanisms (Duranton \& Puga, 2004). We use the employment of financial service sector of the Jiedao $^{7}\left(\right.$ Fin $\left._{i t-1}\right)$ in the starting year to proxy the localization economies and the employment of other advanced producer service sectors $\left(A P S_{i t-1}\right)$ to proxy the urbanization economies.

Second, urban planning and other related policies from the municipal government are very important for the location choice of financial firms. In the Master Plan of Beijing (1991-2010), Financial Street and the CBD were designed to be key districts specialized in financial and other advanced business service. In addition, many financial firms are inclined to locate close to key financial regulators and flagship financial institutions which are headquartered in Beijing. As observed in the previous sections, most influential financial regulators and institutions are located in Financial Street and the CBD. To test the effect of urban planning as well as the tendency to be close to existing important financial institutions, we use the dummy variables of proxy whether a Jiedao is within or near to Financial Street or the CBD. The first dummy variable is whether the Jiedao is within the two key financial districts $\left(\right.$ Area_Fin $\left._{i t-1}\right)$. The second one is whether the Jiedao is the geographically adjacent to the two districts $\left(\right.$ Near_Fin $\left._{i t-1}\right)$.

We also include some controlling factors in the regression models. The finance related business needs intensive interactions based on trust relationship, and face-to-

8 Jiedao, also known as subdistrict, is one of the lowest political administrative in Chinese cities. It is of the same administrative level as township and lower than district in a city. A district of city is made up of several Jiedao. 
face communication is helpful to build up and sustain the mutual trust and also good for safety issue. Therefore, financial service firms might prefer to locate in places with better transportation accessibility as it will be easier for them to reach clients, and vice versa. In this study, we use the number of subway stations of a Jiedao (Cnt_Subway ${ }_{i t-1}$ ) to measure the transportation accessibility, as taking subway, including for financial elites, is the major commuting method in Beijing. In addition, clients of advanced financial service firms are usually headquartered in the inner city (Pan et al., 2015), so the distance between the Jiedao and the city center (Dis_Center $\left.{ }_{i t-1}\right)$ is used to measure the market potential. We also include the residential population of each Jiedao $\left(\right.$ Pop $\left._{i t-1}\right)$ to control the effect of local market demand from residential population within a Jiedao.

We use the following equation to test our major argument:

$$
\begin{aligned}
\text { Empol }_{i t}=\alpha_{0}+ & \alpha_{1} \text { Fin }_{i t-1}+\alpha_{2} \text { APS }_{i t-1}+\alpha_{3} \text { Area_Fin }_{i t-1}+\alpha_{4} \text { Near_Fin }_{i t-1} \\
& +\alpha_{5} \text { Cnt_Subway }_{i t-1}+\alpha_{6} \text { Dis_Center }_{i t-1}+\alpha_{7} \text { Pop }_{i t-1}+\text { error }_{i t}
\end{aligned}
$$

where $E_{\text {Empol }}$ denotes the employment in financial sector of Jiedao $i$ in year $t$. The definitions of all the explanation variables are listed in Table 1. All the independent variables are lagged measurements in the staring year of the research period.

\begin{tabular}{|c|c|c|}
\hline Variables & Definition & Expected Relationship \\
\hline$F_{i n}$ it $-1_{1}$ & Financial employment of the Jiedao & Positive \\
\hline$A P S_{i t-1}$ & $\begin{array}{l}\text { Employment of advanced production } \\
\text { service firms of the Jiedao }\end{array}$ & Positive \\
\hline Area_Fin $_{i t-1}$ & $\begin{array}{l}1 \text { if the Jiedao overlaps with Financial } \\
\text { Street or the CBD, } 0 \text { otherwise }\end{array}$ & Positive \\
\hline Near_Fin ${ }_{i t-1}$ & $\begin{array}{l}1 \text { if the Jiedao is adjent to Financial Street } \\
\text { or the CBD, } 0 \text { otherwise }\end{array}$ & Positive \\
\hline Cnt_Subway $y_{i t-1}$ & Number of subway stations in the Jiedao & Positive \\
\hline Dis_Center $r_{i t-1}$ & $\begin{array}{l}\text { Distance (kilometers) between the Jiedao } \\
\text { to Tiananmen Square }\end{array}$ & Negative \\
\hline Pop $_{i t-1}$ & Number of resident population & Positive \\
\hline
\end{tabular}

Table 1. Definition of independent variables

The regression results are presented in Table 2. Overall, the findings are supportive to the research hypothesis discussed previously. There exist strong agglomeration effects in the geographies of financial service firms in Beijing. The coefficients of $F_{i n} n_{i t-1}$ and $A P S_{i t-1}$ are both significantly positive. It shows that financial service firms prefer to locate in places where many financial service and other advanced producer 
firms already exist. It indicates that just like other sectors, there are strong agglomeration economies and existing industrial cluster in the finance sector (Cook \& Pandit, 2004).

In addition, the coefficients of Area_Fin ${ }_{i t-1}$ and Near_Fin It-1 $_{-1}$ are both significantly positive reflecting the importance of urban planning and being close to key financial regulators and flagship financial institutions in the locational decision of financial service firms. According to the urban planning and other related policies, financial service firms are more likely to obtain friendly supports from the local government when they are located in the specific areas guided by the government. More importantly, since the key financial regulators or other important financial institutions already located in Financial Street and the CBD, newcomers can enjoy the agglomeration economies and accessibility to crucial information in the finance sector. The findings are consistent to one recent study, which found that Chinese banks tend to be close to the Britain's financial regulators and those famous financial institutions when they make locational decisions within London (Hall, 2018).

Some controlling factors are also important in explaining the location of financial service firms. The coefficient of Cnt_Subway ${ }_{i t-1}$ is significantly positive of the year 2010. The result confirms that financial service firms are more likely to locate in areas with better public transportation accessibility with Beijing, given the reliance on public transport as a commuting method in Beijing. For year 2001, the coefficient of Cnt_Subway ${ }_{i t-1}$ is positive but not significant, the reason might be that the subway system of Beijing in 2001 was far away from matured and the measurement cannot reflect the true situation. Being close to city center also seems very important for financial activities, as the coefficients of Dis_Center $_{i t-1}$ are significantly negative in both years. As a typical type of high-end service sector, financial service firms can afford the expensive cost in the inner city.

Table 2. Regression results of distribution of financial employment

\begin{tabular}{|c|c|c|c|c|}
\hline & \multicolumn{2}{|c|}{2001} & \multicolumn{2}{|c|}{2010} \\
\hline & Coefficient & $\mathrm{P}$ & Coefficient & $\mathrm{p}$ \\
\hline $\boldsymbol{F i n}_{i t-1}$ & $0.775 * * *$ & 0.001 & $1.785 * * *$ & 0.001 \\
\hline$A P S_{i t-1}$ & $0.067 * * *$ & 0.006 & $0.015 * * *$ & 0.008 \\
\hline
\end{tabular}




\begin{tabular}{|c|c|c|c|c|}
\hline Area_Fin ${ }_{i t-1}$ & $4759.335 * * *$ & 0.000 & $2478.369 * * *$ & 0.000 \\
\hline Near_Fin ${ }_{i t-1}$ & $1259.137 * * *$ & 0.003 & $986.058 * *$ & 0.037 \\
\hline Cnt_Subway ${ }_{i t-1}$ & 76.128 & 0.136 & $113.658 * * *$ & 0.008 \\
\hline Dis_Center $_{i t-1}$ & $-2.169 * *$ & 0.045 & $-0.518^{*}$ & 0.085 \\
\hline Pop $_{i t-1}$ & -0.001 & 0.685 & $-0.004 * *$ & 0.025 \\
\hline Constant & 34.495 & 0.436 & 37.153 & 0.743 \\
\hline $\mathrm{N}$ & \multicolumn{2}{|c|}{320} & \multicolumn{2}{|c|}{320} \\
\hline $\mathrm{F}$ & \multirow{2}{*}{\multicolumn{2}{|c|}{52.953}} & \multicolumn{2}{|c|}{315.486} \\
\hline Prob > F & & & \multicolumn{2}{|c|}{0.000} \\
\hline Adjusted $R^{2}$ & \multicolumn{2}{|c|}{0.000} & \multicolumn{2}{|c|}{0.885} \\
\hline
\end{tabular}

Note: $* * *$ denotes the significance at $1 \%$ level, $* *$ denotes the significance at $5 \%$ level, $*$ denotes the significance at $10 \%$ level.

While the locational behaviour of financial service firms from varied subsectors might be different due to their distinctive nature of businesses, we run more regressions on the employment of banking, securities, and insurance in each Jiedao separately. Overall, as shown in Table 3, the geography patterns of banking activities are different from the other two types of financial activities. For securities and insurance firms, there exist stronger agglomeration effects as the coefficients of Fin $_{i t-1}$ and $A P S_{i t-1}$ are both significantly positive. However, the coefficient of $A P S_{i t-1}$ is not statistically significant for the bank sector, which indicates that banks do not tend to strongly agglomerate with each other as securities and insurance firms do. Finally, securities and insurance firms are strongly inclined to locate in Financial Street and the CBD as the coefficients of Area_Fin ${ }_{i t-1}$ and Near_Fin Nt-1 $_{1}$ are both significantly positive, while the coefficient of Area_Fin ${ }_{i t-1}$ for bank sector is positive but not statistically significant.

The banking activities are more related to residential population, as the coefficient of $P_{o p} p_{i-1}$ is significantly positive for bank sector. But for the securities and insurance sector, the relationships between residential population and employment in Jiedao are negative. One reason might be that many banks mainly provide retail banking services for residential population rather than whole sale service for corporation clients. In addition, the results show that banks prefer to be close to subway station as the coefficient of Cnt_Subway ${ }_{i t-1}$ is significantly positive, but the coefficient is not statistically significant for securities and insurance sector.

Table 3. Regression results of the distribution of employment in bank, securities and insurance sectors in 2010

\begin{tabular}{|c|c|c|c|c|c|c|}
\hline & \multicolumn{2}{|c|}{ Bank sector } & \multicolumn{2}{|c|}{ Securities sector } & \multicolumn{2}{|c|}{ Insurance sector } \\
\hline & Coefficient & $p$ & Coefficient & $p$ & Coefficient & $\mathrm{p}$ \\
\hline $\operatorname{Fin}_{i t-1}$ & $1.549 * * *$ & 0.000 & $0.928 * * *$ & 0.000 & $1.361 * * *$ & 0.000 \\
\hline
\end{tabular}




\begin{tabular}{|c|c|c|c|c|c|c|}
\hline$A P S_{i t-1}$ & 0.009 & 0.225 & $0.007 *$ & 0.071 & $0.010^{* *}$ & 0.035 \\
\hline Area_Fin ${ }_{i t-1}$ & 301.584 & 0.652 & $1567.099 * * *$ & 0.000 & $4758.242 * * *$ & 0.000 \\
\hline Near_Fin ${ }_{i t-1}$ & $624.153^{*}$ & 0.079 & $556.357 * * *$ & 0.005 & $565.653^{* *}$ & 0.048 \\
\hline Cnt_Subway $_{i t-1}$ & $97.948 * *$ & 0.012 & 3.985 & 0.753 & 53.963 & 0.157 \\
\hline Dis_Center $_{i t-1}$ & -0.421 & 0.847 & -1.296 & 0.257 & -0.412 & 0.895 \\
\hline $\boldsymbol{P o p}_{i t-1}$ & $0.002 * *$ & 0.017 & -0.001 & 0.762 & $-0.011 * * *$ & 0.007 \\
\hline Constant & 13.736 & 0.869 & 84.857 & 0.235 & 32.624 & 0.652 \\
\hline $\mathrm{N}$ & \multicolumn{2}{|c|}{320} & \multicolumn{2}{|c|}{320} & \multirow{2}{*}{\multicolumn{2}{|c|}{$\begin{array}{c}320 \\
05538\end{array}$}} \\
\hline F & \multicolumn{2}{|c|}{91.756} & \multicolumn{2}{|c|}{39.452} & & \\
\hline Prob > F & \multicolumn{2}{|c|}{0.000} & \multicolumn{2}{|l|}{0.000} & \multicolumn{2}{|l|}{$\begin{array}{c}95.538 \\
0.000\end{array}$} \\
\hline Adjusted $\mathrm{R}^{2}$ & \multicolumn{2}{|c|}{0.672} & \multicolumn{2}{|l|}{0.459} & \multicolumn{2}{|l|}{0.658} \\
\hline
\end{tabular}

Note: ${ }^{* * *}$ denotes the significance at $1 \%$ level, ${ }^{* *}$ denotes the significance at $5 \%$ level, ${ }^{*}$ denotes the significance at $10 \%$ level.

We do the robust check by using the number of financial service firms in the ending years as the dependent variable in the regressions. Meanwhile, we use the number of firms in the starting years as independent variables to measure localization and urbanization economies. The results are similar and the findings still hold (Please see the Appendix).

\section{Conclusion and discussion}

This paper analyzes the geography of the financial service industry in Beijing based on firm level data. The results show that financial activities in Beijing have been concentrating in the inner city over time. The clustering process of financial firms in Beijing is rapid and two particularly significant financial service clusters have emerged: one in Financial Street that concentrates on banks and securities companies and the second in the $\mathrm{CBD}$ that functionally specializes in insurance and venture capital companies. While market forces, in particular, the agglomeration economies are important to the concentrating process, policy interventions from the municipal government is an important factor in explaining the formation of the two key financial districts in Beijing. The further regression analysis confirms that both the market and state forces have significantly shaped the spatial pattern of financial activities in Beijing.

Our analysis of the evolution of financial services firms' geographies within Beijing also draws attention to extending studies on the locational behaviours of financial activities beyond financial centers in the Global North. Here, the research presented in this paper provides an important case study from an emerging economy in 
which there exists strict regulation on the financial sector and the state plays an important role in the economy. Here, the paper reports that whilst agglomeration economies are found to be important in ways that echo the experience of Beijing's western counterparts (Cook et al., 2007), the intervention from municipal government has also been a very strong factor shaping the development of financial districts in Beijing from their earliest conception. This reflects the fact that Beijing's municipal government has actively sought to promote the clustering of financial services firms to follow role models in Western countries through planning and other policy tools.

Moreover, the changing intra-city geographies of financial activities in Beijing show that the intersection between national and municipal government policy and regulation is central in accounting for Beijing's development as an IFC, reflecting wider debates on the importance to understanding the role of politics and policymaking in shaping finance landscape at a range of spatial resolutions (Agnew, 2010; Hall, 2017). On the one hand, due to the national designation, Beijing is not as aggressive as other cities in promoting its image as an IFC despite its strong competitiveness in the financial sector. As a result, Beijing's reputation as an IFC is not as well developed as that of Shanghai. On the other hand, Beijing's municipal government has strong motivations to develop the financial sector as part of its wider economic development strategy. In this respect, Beijing has sought to capitalize on the location of key national financial regulators and flagship financial institutions in the city due to its role as a capital city in order to facilitate its development as an IFC. This has resulted in attracting more financial firms into the city with an associated growth in financial services employment. The success to date of this aim can be seen in the development of two key financial district in Beijing. However, the future trajectory of these districts, alongside emerging ones such as those linked with venture capital as found in Zhongguancun will be shaped by the interplay of municipal and national policy agendas alongside the imperatives of agglomeration economies and wider changes in the international financial system and China's place within it. 
(No. 41871157), the Fundamental Research Funds for the Central Universities

(No.2012LYB36, No. 2013YB06) and Beijing Higher Education Young Elite Teacher Project

(No.YETP0290).

Declaration of interest: No potential conflict of interest was reported by the authors.

\section{References}

Agnew, J. (2010) Emerging China and critical geopolitics: Between world politics and Chinese particularity. Eurasian Geography and Economics, 51, 569-582.

Bassens, D., E. Engelen, B. Derudder \& F. Witlox (2013) Securitization across borders: organizational mimicry in Islamic finance. Journal of Economic Geography, 13, 85-106.

Beaverstock, J. (2004) Managing across borders: knowledge management and expatriation in professional service legal firms. Journal of Economic Geography, 4, 157-179.

Beaverstock, J. V. (2005) Transnational elites in the city: British highly-skilled inter-company transferees in New York City's financial district. Journal of Ethnic and Migration Studies, 31, 245-268.

Beaverstock, J. V. \& S. Hall (2012) Competing for talent: global mobility, immigration and the City of London's labour market. Cambridge Journal of Regions Economy and Society, 5, 271-287.

BJMBFW \& BJMCDR (2011) "Beijing Twelfth Five Year Plan of the Finance Industry" Beijing Municipal Bureau of Financial Work and Beijing Municipal Commission on Development and Reform, Beijing.

BJMC and BJMG (2008) "Beijing Municipal Committee and Beijing Municipal Government's Opinions on How to Develop Finance Industry of the Capital (Jingfa [2008], No.8)" Beijing Municipal Committee of CPC and Beijing Municipal Government, Beijing.

Botev, Z. I., J. F. Grotowski \& D. P. Kroese (2010) Kernel density estimation via diffusion. Annals of Statistics, 38, 2916-2957.

Cassis, Y. \& D. Wójcik. 2018. International financial centers after the global financial crisis and Brexit. Oxford University Press.

Chubarov, I. \& D. Brooker (2013) Multiple pathways to global city formation: A functional approach and review of recent evidence in China. Cities, 35, 181-189.

Clare, A., M. A. Gulamhussen \& C. Pinheiro (2013) What factors cause foreign banks to stay in London? Journal of International Money and Finance, 32, 739-761.

Cook, G. \& N. R. Pandit (2004) Clustering in the British Broadcasting and Financial Services Industries: A Comparative Analysis of Three Regions. Problems and Perspectives in Management, 72-88.

Cook, G. A. S., N. R. Pandit, J. V. Beaverstock, P. J. Taylor \& K. Pain (2007) The role of location in knowledge creation and diffusion: evidence of centripetal and centrifugal forces in the City of London financial services agglomeration. Environment and Planning A, 39, 1325-1345.

CSC (2009) "State Council's Opinions on How to Promote Shanghai to Develop Modern Producer Service and Advanced Manufacturing Industries and Become International Shipping Center and Financial Center (Guofa, [2009], No.19)", China State Council. 
Duranton, G. \& D. Puga (2004) Micro-foundations of urban agglomeration economies. Handbook of regional and urban economics, 2063-2117.

Engelen, E. (2007) Amsterdamned'? The uncertain future of a financial center. Environment and Planning A, 39, 1306.

Engelen, E. \& M. H. Grote (2009) Stock exchange virtualisation and the decline of second-tier financial centers-the cases of Amsterdam and Frankfurt. Journal of Economic Geography, 9, 679-696.

French, S., A. Leyshon \& T. Wainwright (2011) Financializing space, spacing financialization. Progress in human geography, 35, 798-819.

Gong, H. \& K. Keenan (2012) The Impact of 9/11 on the Geography of Financial Services in New York: A Few Years Later. Professional Geographer, 64, 370-388.

Grote, M. H. (2003) The evolution of the financial center Frankfurt. Geographische Zeitschrift, 91, 200217.

Hall, S. (2017) Rethinking international financial centres through the politics of territory: renminbi internationalisation in London's financial district. Transactions of the Institute of British Geographers, 42, 489-502.

Hall, S. (2018) Regulating the geographies of market making: offshore Renminbi markets in London's international financial district. Economic Geography, 94(3), 259-278.

Karreman, B. \& B. van der Knaap (2009) The financial centers of Shanghai and Hong Kong: competition or complementarity? Environment and Planning A, 41, 563-580.

Knox-Hayes, J. (2009) The developing carbon financial service industry: expertise, adaptation and complementarity in London and New York. Journal of Economic Geography, 9, 749-777.

Kynaston, D. (2002) The City of London. Volume IV: A club no more 1945-2000. London, UK: Pimlico.

Lai, K. (2012) Differentiated Markets: Shanghai, Beijing and Hong Kong in China's Financial Center Network. Urban Studies, 49, 1275-1296.

Leyshon, A. \& N. J. Thrift. (1997) Money/space: Geographies of Monetary Transformation. Psychology Press.

Liu, W. \& W. Wu (2008) Development of local financial systems in mainland China. Eurasian Geography and Economics, 49, 160-179.

Pain, K. (2008) Spaces of practice in advanced business services: rethinking London - Frankfurt relations. Environment and Planning D-Society \& Space, 26, 264-279.

Pan, F., W. Bi, J. Lenzer \& S. Zhao (2017) Mapping urban networks through inter-firm service relationships: the case of China. Urban Studies, 54, 3639-3654.

Pan, F. H., J. Guo, H. Zhang \& J. S. Liang (2015) Building a "Headquarters Economy": The geography of headquarters within Beijing and its implications for urban restructuring. Cities, 42, 1-12.

Pan, F., Z. He, T. Sigler, K. Martinus \& B. Derudder (2018) How Chinese Financial Centers Integrate into Global Financial Center Networks: An Empirical Study Based on Overseas Expansion of Chinese Financial Service Firms. Chinese Geographical Science, 28, 217-230.

Pan, F., S. X. B. Zhao \& D. Wójcik (2016) The rise of venture capital centers in China: A spatial and network analysis. Geoforum, 75, 148-158.

Pan, F. H., S. X. B. Zhao \& D. Wojcik (2016) The rise of venture capital centers in China: A spatial and network analysis. Geoforum, 75, 148-158.

Pollard, J. \& M. Samers (2007) Islamic banking and finance: postcolonial political economy and the decentring of economic geography. Transactions of the Institute of British Geographers, 32, 313-330. 
Porter, M. E. (1980) Competitive Strategy. New York: Free Press

Puga, D. (2010) The magnitude and causes of agglomeration economies. Journal of Regional Science, $50,17$.

Sassen, S. (2001) The Global City: New York, London, Tokyo. Princeton University Press.

SHMG (1986) "Shanghai City Master Plan Scheme", Shanghai Municipal Government.

SHMG (2001) " Shanghai City Master Plan (1999-2020)", Shanghai Municipal Government.

Taylor, P., B. Derudder, M. Hoyler, P. Ni \& F. Witlox (2013) City-Dyad Analyses of China's Integration into the World City Network. Urban Studies.

Taylor, P. J., B. Derudder, J. Faulconbridge, M. Hoyler \& P. Ni (2014) Advanced Producer Service Firms as Strategic Networks, Global Cities as Strategic Places. Economic Geography, 90, 267-291.

Timberlake, M., Y. D. Wei, X. Ma \& J. Hao (2014) Global cities with Chinese characteristics. Cities, 41, 162-170.

Wójcik, D. (2013) The Dark Side of NY-LON: Financial Centers and the Global Financial Crisis. Urban Studies, 50, 2736-2752.

Wójcik, D., E. Knight \& V. Pažitka (2018) What turns cities into international financial centers? Analysis of cross-border investment banking 2000-2014. Journal of Economic Geography, 18, 1-33.

Walter, C. \& F. Howie. 2011. Red Capitalism: The Fragile Financial Foundation of China's Extraordinary Rise. John Wiley \& Sons.

Wei, Y. D. \& D. Yu (2006) State policy and the globalization of Beijing: emerging themes. Habitat International, 30, 377-395.

Woo, J. J. (2015) Beyond the neoliberal orthodoxy: alternative financial policy regimes in Asia's financial centers. Critical Policy Studies, 9, 297-316.

Yao, Y. \& L. Shi (2012) World city growth model and empirical application of Beijing. Chinese Management Studies, 6, 204-215.

Yusuf, S. \& W. Wu (2002) Pathways to a World City: Shanghai Rising in an Era of Globalisation. Urban Studies, 39, 1213-1240.

Zhang, J. (2011) The spatial dynamics of globalizing venture capital in China. Environment and Planning A, 43, 1562-1580.

Zhang, L.-Y. (2014) Dynamics and Constraints of State-led Global City Formation in Emerging Economies: The Case of Shanghai. Urban Studies, 51(6), 1162-1178.

Zhao, S. X. B. (2013) Information Exchange, Headquarters Economy and Financial Centers Development: Shanghai, Beijing and Hong Kong. Journal of Contemporary China, 22, 1006-1027.

Zhao, S. X. B., L. Zhang \& D. T. Wang (2004) Determining factors of the development of a national financial center: the case of China. Geoforum, 35, 577-592.

Zhou, Y. U. (1998) Beijing and the Development of Dual Central Business Districts. Geographical Review, $88,429-436$.

\section{Appendix}

Table A1. Regression results of the number of financial service firms

\begin{tabular}{lccccc}
\hline & \multicolumn{2}{c}{2001} & & \multicolumn{2}{c}{2010} \\
\cline { 2 - 3 } \cline { 5 - 6 } & Coefficient & $\mathrm{P}$ & & Coefficient & $\mathrm{p}$ \\
\hline $\boldsymbol{F i n}_{\boldsymbol{i t - 1}}$ & $0.526^{* * *}$ & 0.000 & & $1.025^{* * *}$ & 0.008 \\
$\boldsymbol{A P S}_{\boldsymbol{i t}-\mathbf{1}}$ & $0.043^{*}$ & 0.086 & & $0.009^{* *}$ & 0.039 \\
\hline
\end{tabular}




\begin{tabular}{|c|c|c|c|c|}
\hline Area_Fin $_{i t-1}$ & $53.564 * * *$ & 0.005 & $68.761 * * *$ & 0.003 \\
\hline Near_Fin ${ }_{i t-1}$ & $119.258 * *$ & 0.043 & $59.065 *$ & 0.052 \\
\hline Cnt_Subway $_{i t-1}$ & 59.020 & 0.125 & $21.624 * *$ & 0.025 \\
\hline Dis_Center $_{i t-1}$ & $-2.158 * *$ & 0.046 & $-0.247 *$ & 0.083 \\
\hline Pop $_{i t-1}$ & -0.001 & 0.796 & $-0.003 * *$ & 0.043 \\
\hline Constant & 15.348 & 0.489 & 3.209 & 0.754 \\
\hline $\mathrm{N}$ & \multicolumn{2}{|c|}{320} & \multicolumn{2}{|c|}{320} \\
\hline F & \multicolumn{2}{|c|}{41.257} & \multicolumn{2}{|c|}{259.523} \\
\hline Prob $>$ F & \multicolumn{2}{|c|}{0.000} & \multicolumn{2}{|c|}{0.000} \\
\hline Adjusted $R^{2}$ & \multicolumn{2}{|c|}{0.397} & \multicolumn{2}{|c|}{0.561} \\
\hline
\end{tabular}

Note: $* * *$ denotes the significance at $1 \%$ level, $* *$ denotes the significance at $5 \%$ level, $*$ denotes the significance at $10 \%$ level.

Table A2. Regression results of the number of financial service firms in bank, securities and insurance sectors in 2010

\begin{tabular}{|c|c|c|c|c|c|c|}
\hline & \multicolumn{2}{|c|}{ Bank sector } & \multicolumn{2}{|c|}{ Securities sector } & \multicolumn{2}{|c|}{ Insurance sector } \\
\hline & Coefficient & $\mathrm{p}$ & Coefficient & $p$ & Coefficient & $\mathrm{p}$ \\
\hline Fin $_{i t-1}$ & $0.439 * *$ & 0.032 & $0.211 * * *$ & 0.000 & $0.379^{* * *}$ & 0.000 \\
\hline$A P S_{i t-1}$ & 0.003 & 0.259 & $0.005^{*}$ & 0.076 & $0.009 * *$ & 0.046 \\
\hline Area_Fin $_{i t-1}$ & 35.564 & 0.542 & $13.256^{* * *}$ & 0.000 & $23.679 * * *$ & 0.000 \\
\hline Near_Fin ${ }_{i t-1}$ & $12.593^{*}$ & 0.096 & $34.925^{* *}$ & 0.036 & $15.582 *$ & 0.086 \\
\hline Cnt_Subway ${ }_{i t-1}$ & $10.468 * *$ & 0.042 & 1.624 & 0.242 & 5.578 & 0.159 \\
\hline Dis_Center $_{i t-1}$ & -0.195 & 0.631 & -0.457 & 0.176 & -0.146 & 0.733 \\
\hline Pop $_{i t-1}$ & $0.002 * *$ & 0.011 & -0.001 & 0.734 & $-0.018 * * *$ & 0.007 \\
\hline Constant & 3.452 & 0.439 & 9.578 & 0.359 & 10.147 & 0.422 \\
\hline $\mathrm{N}$ & 320 & & 320 & & 320 & \\
\hline $\mathrm{F}$ & 49.285 & & 29.7 & & 56.358 & \\
\hline Prob > F & 0.000 & & 0.00 & & 0.000 & \\
\hline Adjusted $\mathrm{R}^{2}$ & 0.433 & & 0.36 & & 0.456 & \\
\hline
\end{tabular}

Note: ${ }^{* * *}$ denotes the significance at $1 \%$ level, ${ }^{* *}$ denotes the significance at $5 \%$ level, ${ }^{*}$ denotes the significance at $10 \%$ level. 